\title{
Tomato yellow leaf curl virus Can Overwinter in Stellaria aquatica, a Winter-Hardy TYLCV-Reservoir Weed
}

Eui-Joon Kil, Department of Genetic Engineering and The Institute of Life Science and Technology, Sungkyunkwan University, Suwon 440-746, Republic of Korea; Hee-Seong Byun, Sunhoo Kim, Seungchan Cho, Sungrae Cho, and Kangsan Roh, Department of Genetic Engineering, Sungkyunkwan University; Kyeong-Yeoll Lee, Institute of Plant Medicine, Kyungpook National University, Daegu 702-701, Republic of Korea; Hong-Soo Choi and Chang-Seok Kim, Crop Protection Division, National Academy of Agricultural Science, Rural Development Administration, Wanju 565-851, Republic of Korea; and Sukchan Lee, Department of Genetic Engineering, Sungkyunkwan University

\begin{abstract}
Kil, E.-J., Byun, H.-S., Kim, S., Cho, S., Cho, S., Roh, K., Lee, K.-Y., Choi, H.-S., Kim, C.-S., and Lee, S. 2015. Tomato yellow leaf curl virus can overwinter in Stellaria aquatica, a winter-hardy TYLCV-reservoir weed. Plant Dis. 99:588-592.

Tomato yellow leaf curl virus (TYLCV), one of the most serious plant viruses in tropical and subtropical regions, is transmitted to host plants by the vector insect Bemisia tabaci. In order to control TYLCV, it is important to identify weed hosts for overwintering TYLCV. Stellaria aquatica, a winterhardy weed, was found growing with TYLCV-infected tomato plants in greenhouse production. TYLCV was detected in $S$. aquatica plants by polymerase chain reaction and Southern blot hybridization analysis. The intergenic region nucleotide sequences amplified from TYLCVinfected tomato plants, TYLCV-viruliferous whiteflies, and S. aquatica were identical. During winter (December to February), TYLCV-viruliferous whiteflies and TYLCV-infected tomato plants were removed or absent from

greenhouses. However, S. aquatica plants were observed over a period of 10 months from August to May in such greenhouses, and TYLCV was consistently detected in some of these plants. To investigate the transmission of TYLCV from TYLCV-infected $S$. aquatica plants to healthy tomato plants by whiteflies, TYLCV-infected $S$. aquatica plants were transplanted to pots in cages with nonviruliferous whiteflies and healthy tomato plants. After 4 weeks, tomato plants developed typical TYLCV disease symptoms, and TYLCV was detected in both whiteflies and tomato plants. These results show that $S$. aquatica can act as a winter-hardy reservoir for TYLCV, and suggest that this weed could play an important role in overwintering of TYLCV in tomato greenhouses.
\end{abstract}

Tomato yellow leaf curl virus (TYLCV) is a plant virus affecting tomato (Solanum lycopersicum) cultivation in tropical and subtropical regions (5). It belongs to the genus Begomovirus of the family Geminiviridae and consists of a single-stranded circular DNA genome encapsidated in a twinned icosahedral virion (14). TYLCV is transmitted to host plants by the vector insect, sweet potato whitefly (Bemisia tabaci) (7). TYLCV-infected tomato plants show symptoms including curling, interveinal yellowing of leaves, and severe stunting (17). Tomato yellow leaf curl disease (TYLCD) can cause severe tomato production loss.

In the Republic of Korea, TYLCD in tomato was first reported in 2008, and it rapidly spread through the country (13). Until now, TYLCD has been continuously reported from tomato cultivating areas. Tomato plants are cultivated in two different cultivation cycles in the Republic of Korea: winter and nonwinter. The winter cultivation is carried out from October to July inside heated greenhouses, whereas the nonwinter cultivation is conducted from April to November in nonheated greenhouses.

Other cultivated plants can be hosts of TYLCV, including pepper (Capsicum spp.), common bean (Phaseolus vulgaris), and eustoma (Eustoma grandiflora) $(1,3,14,15,20)$. A number of weeds, including $S$. nigrum, Conyza sumatrensis, and Lamium amplexicaule, have been identified as TYLCV hosts $(2,10,12,17)$. Furthermore, TYLCV has also been detected in many other weed species from families such as Amaranthaceae, Asclepiadaceae, Caparidaceae, Compositae, Cucurbitaceae, Euphorbiaceae, Leguminosae, Malvaceae, Nyctaginaceae, and Solanaceae $(10,17,23)$. In temperate regions, some weeds are winter-hardy and may harbor viruses between cropping seasons; in

Corresponding authors: S. Lee; E-mail: cell4u@skku.edu; and C.-S. Kim; E-mail: rdacskim@korea.kr

Accepted for publication 16 December 2014.

http://dx.doi.org/10.1094/PDIS-04-14-0352-RE

(C) 2015 The American Phytopathological Society these regions, it is very important to identify weed hosts for overwintering TYLCV in order to control TYLCV transmission to new tomato crops. Overwintering of plant viruses in weeds has been reported in some studies on virus-weed interactions $(9,21)$ but it has not been investigated for TYLCV. The importance of identifying TYLCV weed hosts was emphasized in previous studies but verifying transmission of TYLCV from most potential weed hosts, including winter-hardy ones, by whiteflies to healthy tomato plants has not been done (23).

In our previous report, TYLCV was detected in 25 species of weeds belonging to 11 families (12). Of these, Stellaria aquatica is a perennial weed occurring in the open fields and tomato greenhouses of the Republic of Korea. In this study, S. aquatica plants found in a greenhouse with TYLCV-infected tomato plants were monitored over the winter into the next production system. In addition, whitefly-mediated transmission from TYLCV-infected $S$. aquatica to healthy tomato plants was shown.

\section{Materials and Methods}

Plant sample collection. In 2012, TYLCV-infected tomato plants were found in a greenhouse in Suwon (located in the middle area of the Korean peninsula). Several weeds, including $S$. aquatica, were growing in the greenhouse with TYLCV-infected tomato plants (Fig. 1A). Seven $S$. aquatica plants grown near tomato plants showing typical TYLCV symptoms were randomly collected. High populations of adult whiteflies as well as nymphs and eggs were observed on the abaxial surface of leaves of $S$. aquatic plants (Fig. 1B).

DNA extraction and polymerase chain reaction analysis. To detect TYLCV, the Dellaporta method was used (6) to extract total DNA from insects and leaf samples of $S$. aquatica and tomato plants. Viral DNA was amplified by polymerase chain reaction (PCR). Amplification was performed in a $20-\mu$ l reaction mixture containing $2 \times$ Taq PCR MasterMix (Bioneer, Daejeon, the Republic of Korea) and the TYLCVspecific primer set (F: 5'-TTTCCTGAATCTGTTCACGGATT-3' and 5'AACTAATGCCTGTTCCTTCATTC-3') designed in our previous study (18). The following conditions for PCR reaction were employed: preheating at $94^{\circ} \mathrm{C}(3 \mathrm{~min})$; then, 30 cycles of $30 \mathrm{~s}$ at $94^{\circ} \mathrm{C}, 30 \mathrm{~s}$ at $55^{\circ} \mathrm{C}$, and $30 \mathrm{~s}$ at $72^{\circ} \mathrm{C}$; followed by a final extension at $72^{\circ} \mathrm{C}(10 \mathrm{~min})$. 
Intergenic region sequencing. To compare viral nucleotide sequences from TYLCV-infected tomato plants, $S$. aquatica, and TYLCV-viruliferous whiteflies, sequencing and multiple alignments of the intergenic region (IR) was performed. The IR of TYLCV was amplified by PCR with the primers $5^{\prime}$-CTGTTCACGGATTTCGTTGT-3' and 5'-ATATCCCAATTGTTCTCTCTC-3' (Fig. 2B). PCR-amplified fragments were ligated into pGEM-T easy vector (Promega Corp.) and sequenced (Macrogen, Seoul, the Republic of Korea). The sequences were analyzed using MultAlin multiple alignment program (http:// multalin.toulouse.inra.fr/multalin/) (4).

Southern blot hybridization analysis. Southern blot hybridization analysis was performed as described previously (12). Total DNA $(15 \mu \mathrm{g})$ isolated from $S$. aquatica was loaded on a $1 \%$ agarose gel, fractionated by electrophoresis at $25 \mathrm{~V}$ for $16 \mathrm{~h}$, and transferred to Hybond $\mathrm{N}+$ nylon membrane (GE Healthcare Life Sciences, Uppsala, Sweden). To prepare probes, a PCR-amplified DNA fragment from the TYLCV capsid protein coding region was gel purified and labeled with $\left[\alpha{ }^{32} \mathrm{P}\right] \mathrm{dCTP}$ using the Rediprime II Random Primer Labeling System (GE Healthcare Life Sciences). Hybridization was conducted at $65^{\circ} \mathrm{C}$ for $16 \mathrm{~h}$. The nylon membrane was washed with $50 \mathrm{ml}$ of $2 \times \mathrm{SSC}(1 \times \mathrm{SSC}$ is $0.15 \mathrm{M} \mathrm{NaCl}$ plus $0.015 \mathrm{M}$ sodium citrate) buffer and $0.1 \%$ sodium dodecyl sulfate (SDS), then with $1 \times$ SSC and $0.1 \%$ SDS for $1 \mathrm{~h}$ for each wash. After washing, membrane was exposed to X-ray film for approximately $48 \mathrm{~h}$ at $-70^{\circ} \mathrm{C}$ freezer.

Quantitative real-time PCR. For quantification of the level of viral DNA in TYLCV-infected plant samples which showed positive results in PCR from a greenhouse, real-time PCR was performed with five samples of $S$. aquatica and tomato confirmed as TYLCV-infected plants from previous results of PCR and Southern blot analyses. The primer set introduced from the previous study was used ( $5^{\prime}$-TGTTGTAAGGG CCCGTGACT-3' 5'-GACGGGCGTGGAAATGATTA-3') (16). Amplification was carried out using SYBR Premix Ex Taq (Tli RNaseH
Plus; TaKaRa, Shiga, Japan) in a Rotor-Gene Q (Qiagen, Hilden, Germany) following the manufacturers' recommended protocols.

Virus overwintering experiment. To confirm the capacity of TYLCV to overwinter in S. aquatica, TYLCV-infected tomato and S. aquatica plants were allowed to grow for 10 months (from August 2012 to May 2013) in an unheated greenhouse. Greenhouse temperature was measured daily, and Suwon area temperature was obtained from the official Korea Meteorological Administration website (http://www.kma.go.kr/weather/climate/past_table.jsp). During virus overwintering experiments, TYLCV detection for three $S$. aquatica plants confirmed as TYLCV-infected was accomplished six times with the PCR analysis described above.

Whitefly-mediated transmission from $S$. aquatica to tomato. Whitefly-mediated TYLCV transmission from TYLCV-infected $S$. aquatica plants to healthy tomato plants was assessed. Nonviruliferous B. tabaci (Q biotype) kindly provided by Dr. Lee (Kyeong-Yeoll, Kyungpook National University) were reared with virus-free tomato plants in a BugDorm-2120 insect-rearing tent (MegaView Science Education Services Co., Taichung, Taiwan). PCR analyses on randomly selected whiteflies were used to confirm the nonviruliferous status of the whiteflies in this colony. TYLCV-infected S. aquatica plants were transplanted to pots, which were then placed in the insect-rearing tents in June 2013; these plants were treated with insecticide three times to ensure whitefly removal over a period of 1 month. After confirming that TYLCV-infected S. aquatica and insect-rearing tents had no whiteflies, the TYLCV-infected $S$. aquatica plants were used as an inoculum source. Three-week-old healthy 'Seogwang' tomato (TYLCV susceptible) plants were used for inoculation. TYLCV-infected S. aquatica and healthy tomato plants were put in individual insect-rearing tents with 30 nonviruliferous whiteflies at $25^{\circ} \mathrm{C}$ with a day length of $12 \mathrm{~h}$. Insect tents rearing nonviruliferous whiteflies with healthy $S$. aquatica and healthy tomato plants were prepared as a negative control group. All plants were observed
A

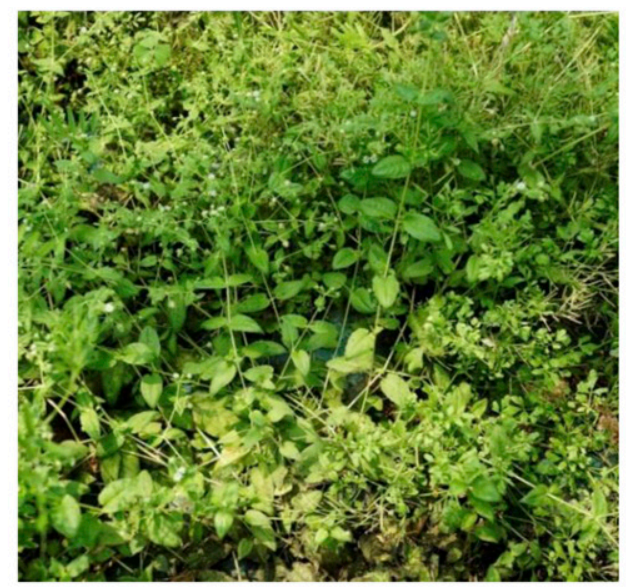

B

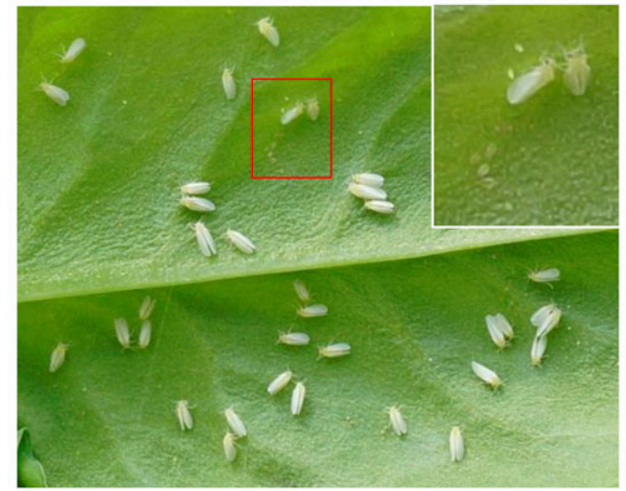

C

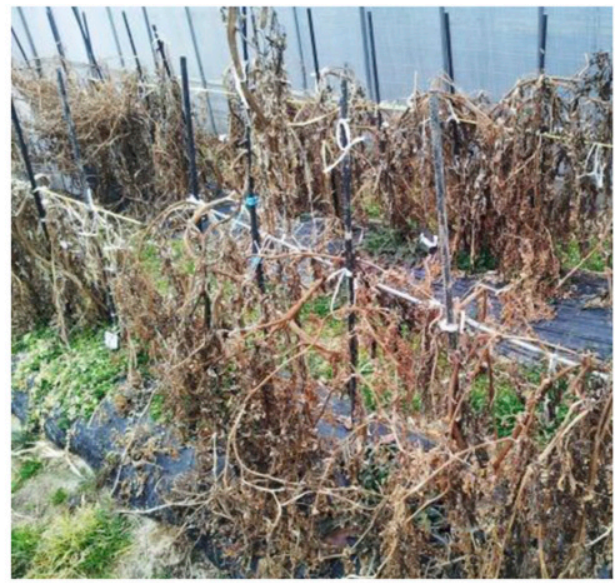

D

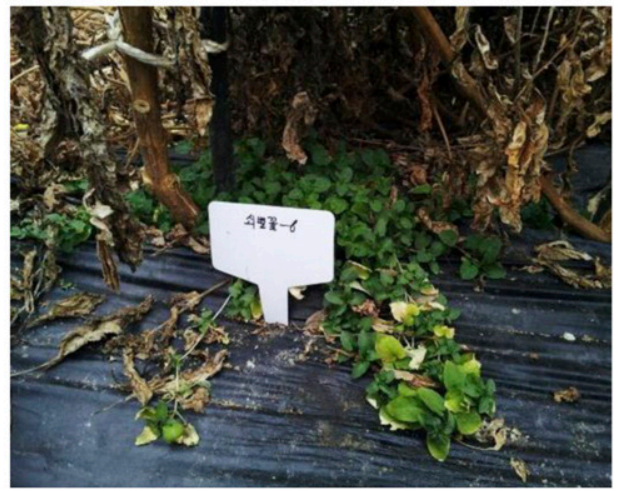

Fig. 1. Stellaria aquatica in a greenhouse with tomato production. A, S. aquatica in summer. B, Bemisia tabaci adults on the abaxial side of S. aquatica leaves. The image of eggs, nymphs, and imagoes of $B$. tabaci is shown in the box in B. C and D, S. aquatica in the winter. 
for symptom development. After 4 weeks, plants were harvested and analyzed for TYLCV infection by PCR analysis.

\section{Results}

S. aquatica in greenhouses harbors TYLCV. S. aquatica plants collected from the Suwon greenhouse where TYLCV-infected tomato plants were found were analyzed by PCR using TYLCV-specific primers. Based on PCR results, TYLCV was detected in four of seven (57.1\%) plants (Fig. 2A). To confirm the replication of the TYLCV in these plants, Southern hybridization with a TYLCV-specific probe was performed. Signals of open-circular and supercoiled doublestranded DNA are shown from three of seven $S$. aquatica plants (Fig. 2D). Results of quantitative real-time PCR analyses showed TYLCV levels in tomato more strongly than $S$. aquatica, and each $S$. aquatica plant showed a different amplification level (Table 1).

Differences in IR sequences were not observed in each infected plant sample. Sequence analyses of the TYLCV IR from TYLCVinfected tomato and S. aquatica were conducted (Fig. 2A). Sequences of all infected samples were confirmed as the IR of TYLCV, and were identical (Fig. 2C). Additionally, the TYLCV IR sequences from whiteflies collected from TYLCV-infected $S$. aquatica leaves were identical to those from TYLCV-infected $S$. aquatica.

TYLCV infected $S$. aquatica survives the winter. $S$. aquatica is a perennial weed that can overwinter in open fields and greenhouses. To determine whether TYLCV-infected $S$. aquatica could act as a TYLCV acquisition source by whiteflies in the subsequent tomato cultivation period, TYLCV-infected tomato plants and three individual $S$. aquatica plants mentioned in the previous experiments in this study (plants 4, 5, and 7) were monitored in the same greenhouse for 10 months from August 2012 to May 2013 (after this, these plants were transplanted for whitefly transmission experiments). During this period, all the tomato plants died, and whiteflies disappeared by October 2012 due to greenhouse temperatures below $10^{\circ} \mathrm{C}$ (Fig. 1C). However, $S$. aquatica showed no change in appearance (i.e., morphology and leaf color), even though the daily minimum temperature dropped to approximately $-10^{\circ} \mathrm{C}$ in January and February 2013 (Fig. 1D). When the daily minimum temperature reached $-20^{\circ} \mathrm{C}$ on 3 January, leaves of $S$. aquatica plants became a slightly yellowish or brown.
A

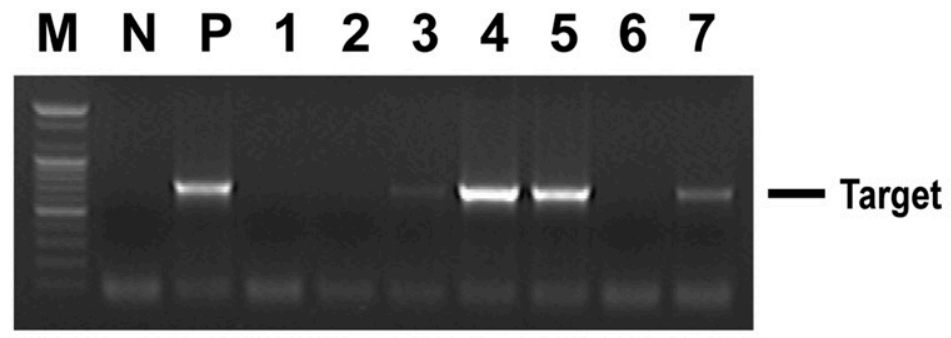

B

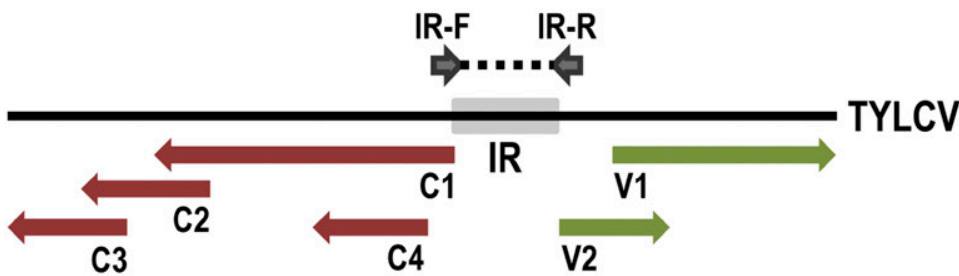

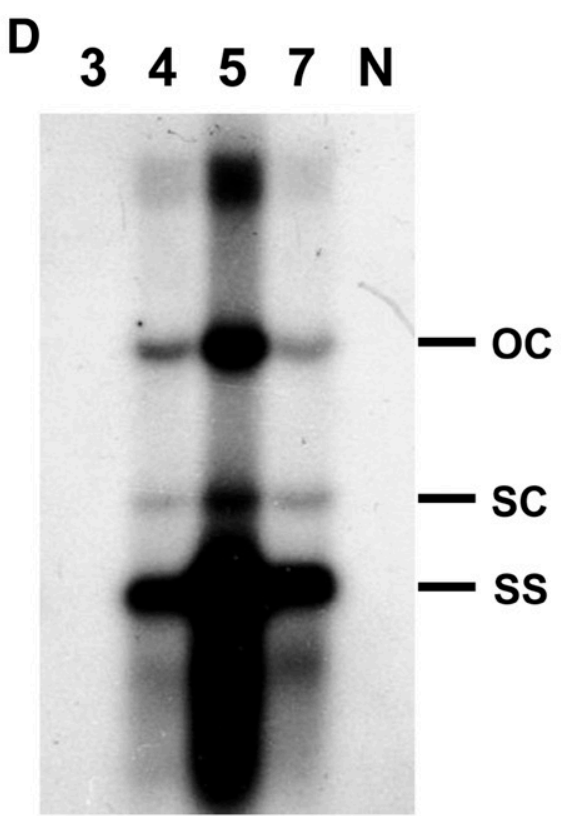

C

Tomato 1 GTTGAAATGA ATCGgTGTCC CTCAAAGCTC TATGGCAATC GGTGTATCGg TGTCTTACTT ATACCTGGAC ACCTAATGGC TATTTGGTAA TTTCATGAAT GTTCATTGTA B. tabaci GTTGAAATGA ATCGGTGTCC CTCAAAGCTC TATGGCAATC GGTGTATCGG TGTCTTACTT ATACCTGGAC ACCTAATGGC TATTTGGTAA TTTCATGAAT GTTCATTGTA s.aquatica-4 GTTGAAATGA ATCGGTGTCC CTCAAAGCTC TATGGCAATC GGTGTATCGG TGTCTTACTT ATACCTGGAC ACCTAATGGC TATTTGGTAA TTTCATGAAT GTTCATTGTA s.aquatica-5 GTTGAAATGA ATCGGTGTCC CTCAAAGCTC TATGGCAATC GGTGTATCGG TGTCTTACTT ATACCTGGAC ACCTAATGGC TATTTGGTAA TTTCATGAAT GTTCATTGTA s.aquatica-7 GTTGAAATGA ATCGGTGTCC CTCAAAGCTC TATGGCAATC GGTGTATCGG TGTCTTACTT ATACCTGGAC ACCTAATGGC TATTTGGTAA TTTCATGAAT GTTCATTGTA Consensus GTTGAAATGA ATCGGTGTCC CTCAAAGCTC TATGGCAATC GGTGTATCGG TGTCTTACTT ATACCTGGAC ACCTAATGGC TATTTGGTAA TTTCATGAAT GTTCATTGTA 111 Hairpin loop

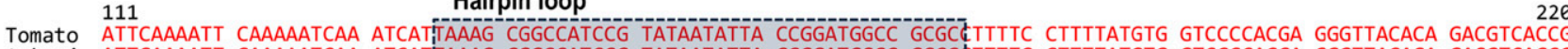
B. tomaci ATTCA B. tabaci ATTCAAAATT CAAAAATCAA ATCATIAAAG CGGCCATCCG TATAATATTA CCGGATGGCC GCGCE TTTTC CTTTTATGTG GTCCCCACGA GGGTTACACA GACGTCACCG S. aquatica-4 ATTCAAAATT CAAAAATCAA ATCATIAAAG CGGCCATCCG TATAATATTA CCGGATGGCC GCGCCTTTTC CTTTTATGTG GTCCCCACGA GGGTTACACA GACGTCACCG S. aquatica-5 ATTCAAAAT CAAAAATCAA ATCATIIAAAG CGGCCATCCG TATAATATTA CCGGATGGCC GCGCETTTTC CTTTTATGTG GTCCCCACGA GGGTTACACA GACGTCACCG s.aquatica-7 ATTCAAAATT CAAAAATCAA ATCATTAAAG CGGCCATCCG TATAATATTA CCGGATGGCC GCGCCTTTTC CTTTTATGTG GTCCCCACGA GGGTTACACA GACGTCACCG Consensus ATTCAAAATT CAAAAATCAA ATCATIAAAG CGGCCATCCG TATAATATTA CCGGATGGCC GCGCLITTTC CTTTTATGTG GTCCCCACGA GGGTTACACA GACGTCACCG 221 TÄTÄ boX

Tomato TCAACCAATC AAATTGCATC CTCAAACGTT AGATAAGTGT TCATTTGTCT ITATATA GTTCCCCAAG

TCAACCAATC AAATTGCATC CTCAAACGTT AGATAAGTGT TCATTTGTCT ITTATATACTT GGTCCCCAAG TTTTTTGTCT TGCAAT

s.aquatica-4 TCAACCAATC AAATTGCATC CTCAAACGTT AGATAAGTGT TCATTTGTCT ITTATATACTT GGTCCCCAAG TTTTTTGTCT TGCAAT

s.aquatica-5 TCAACCAATC AAATTGCATC CTCAAACGTT AGATAAGTGT TCATTTGTCT ITTATATAFTT GGTCCCCAAG TTTTTTGTCT TGCAAT

s.aquatica-7 TCAACCAATC AAATTGCATC CTCAAACGTT AGATAAGTGT TCATTTGTCT ITTATATAFTT GGTCCCCAAG TTTTTTGTCT TGCAAT

Consensus TCAACCAATC AAATTGCATC CTCAAACGTT AGATAAGTGT TCATTTGTCT ITTATATAFTT GGTCCCCAAG TTTTTTGTCT TGCAAT

Fig. 2. Confirmation of TYLCV infection from Stellaria aquatica. A, Polymerase chain reaction (PCR) analysis with a TYLCV-specific primer set. Lane M, 100-bp DNA ladder marker (Bioneer, the Republic of Korea); lane N, no template control; lane P, positive control with TYLCV-infected tomato genomic DNA; and lanes 1 to 7 , genomic DNA from collected S. aquatica plants. B, Linearized diagram of TYLCV DNA and coding sequences (red and green arrows). Gray arrows indicate primer binding site and dotted line shows the expected amplicon containing the intergenic region of TYLCV. C, Multiple alignment of intergenic region sequences from PCR-amplified fragments from TYLCV-infected tomato plants, TYLCV-viruliferous Bemisia tabaci, and TYLCV-infected S. aquatica plants collected from the same greenhouse. D, Southern hybridization analysis with a TYLCV-specific probe. Samples confirmed as TYLCV infected by PCR were followed by Southern hybridization analysis to identify replicating single- and double-stranded viral DNA forms. Lane N, genomic DNA samples extracted from noninfected S. aquatic; OC, open-circular double-stranded DNA; SC, supercoiled double-stranded DNA; and SS, singlestranded DNA. 
New leaves came out later when the temperature rose. To verify TYLCV infection in overwintering $S$. aquatica plants, PCR analyses were performed six times at regular intervals (every 8 weeks) from August 2012 to May 2013. PCR results showed that TYLCV could be continuously detected in S. aquatica over this period of time (Fig. 3B).

TYLCV is transmitted by $B$. tabaci from $S$. aquatica to tomato plants. Under natural conditions, only whiteflies can transmit TYLCV from infected plants to healthy plants. Therefore, it was important to determine whether $S$. aquatica can be a source of TYLCV for whitefly-mediated transmission. The TYLCV-free status of whiteflies and tomato plants was confirmed using PCR analysis (Fig. 4B). After 4 weeks, nonviruliferous whiteflies in three tents with TYLCV-infected $S$. aquatica became TYLCV viruliferous. TYLCV was detected from all tomato plants ( 9 of 9) placed in the three tents with TYLCV-infected S. aquatica (Fig. 4B), whereas tomato plants placed in tents with uninfected $S$. aquatic plants and nonviruliferous whiteflies did not.

\section{Discussion}

Controlling TYLCV is one of the most important issues affecting tomato cultivation in the world. Since the first report of TYLCV from

Table 1. Absolute quantitation of Tomato yellow leaf curl virus by quantitative real-time polymerase chain reaction (PCR) in leaves of tomato and Stellaria aquatica plants from a greenhouse

\begin{tabular}{lc}
\hline Samples & $\mathbf{C}_{\mathbf{T}}$ mean $\pm \mathbf{S D}^{\mathbf{a}}$ \\
\hline Tomato & $12.3 \pm 0.154$ \\
S. aquatica 3 & $31.8 \pm 0.816$ \\
S. aquatica 4 & $23.2 \pm 0.025$ \\
S. aquatica 5 & $19.4 \pm 0.082$ \\
S. aquatica 7 & $24.1 \pm 0.069$ \\
\hline
\end{tabular}

${ }^{a}$ Mean of threshold cycles $\left(\mathrm{C}_{\mathrm{T}}\right)$ and standard deviation (SD) from four independent repeated real-time PCR assays.

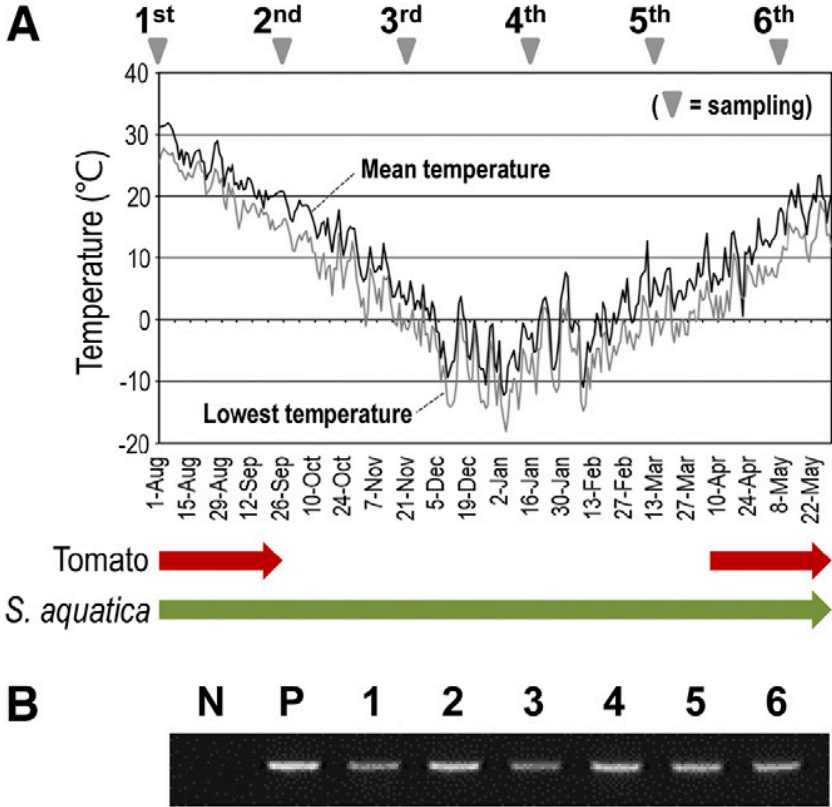

Fig. 3. Confirmation of TYLCV overwintering in Stellaria aquatica. A, Changes of temperature from August to May. The gray-colored line shows daily minimum temperature in the greenhouse and the black line shows mean temperature in Suwon from the official Korea Meteorological Administration website (http://www. kma.go.kr/weather/climate/past_table.jsp). Inverted triangles indicate sampling dates and two arrows display the presence of tomato (red) and S. aquatica (green) in the greenhouse. B, Polymerase chain reaction analysis of the presence of TYLCV using a TYLCV-specific primer set at different time points. Lane N, no template control; lane P, positive control with TYLCV-infected tomato genomic DNA; and lanes 1 to 6 , genomic DNA from S. aquatica (six time points at 1 August, 26 September, and 21 November 2012 and 16 January, 13 March, and 8 May 2013). the southern part of the Korean peninsula in 2008 (13), TYLCV has become endemic and has spread across the Republic of Korea. In the case of nonoverwintering tomato cultivation (April to November), tomato plants and whiteflies are not observed in greenhouses during the winter season (December to February) due to low temperatures. However, in some cases, TYLCD reappears in such greenhouses and affects tomato cultivation beginning in the following spring. One explanation for the reappearance of the virus is nonviruliferous whiteflies acquiring TYLCV from infected weeds and then infecting healthy tomato plants. Another possibility is viruliferous whiteflies coming from winter production in heated greenhouses. A yearround demand for crops and the prevalence of heating facilities enables cultivation throughout the year. In the Republic of Korea, many greenhouses are equipped with heating systems that allow production of vegetables in the winter. Heated greenhouses in winter provide a suitable environment for viruses and their vectors to overwinter and, subsequently, spread to new plantings in the spring, including those in nonheated greenhouses.

Weeds are another possible means of viral overwintering and these would be perennial rather than annual weeds. Epidemiological significance of weeds in TYLCV transmission is well known, and their role as a virus reservoir during crop-free periods has been documented in previous reports $(8,23)$. Surveys for TYLCV weed hosts have been conducted by numerous researchers from different countries $(2,10-12,17,19,22,23)$ and identified in a wide range of potential hosts, most of which were symptomless. However, most of these studies focused on virus detection from field samples; only some have focused on whitefly transmission analyses.

According to our previous study of weeds growing in or around tomato greenhouses in the Republic of Korea, 25 species belonging to 11 families could host TYLCV and most did not show obvious symptoms (12). Even though viral replication was not confirmed in all of these plants by Southern hybridization, plants showing positive PCR results have the potential to be reservoir hosts of TYLCV. The perennial weed $S$. aquatica was found in a tomato greenhouse where TYLCV occurrence was confirmed (Fig. 1). TYLCV was detected in four of seven symptomless $S$. aquatica plants randomly selected for by PCR analysis, and viral replication was also verified in three of seven plants by Southern hybridization (Fig. 2A and D). These results indicate that $S$. aquatica is a symptomless host of TYLCV. Sample number 3, whose PCR product showed a faint band on an agarose gel, was not detected from Southern blot hybridization based on different sensitivity of two detection methods (Fig. 2A and D) (12). A small amount of viral DNA from sample number 3 could
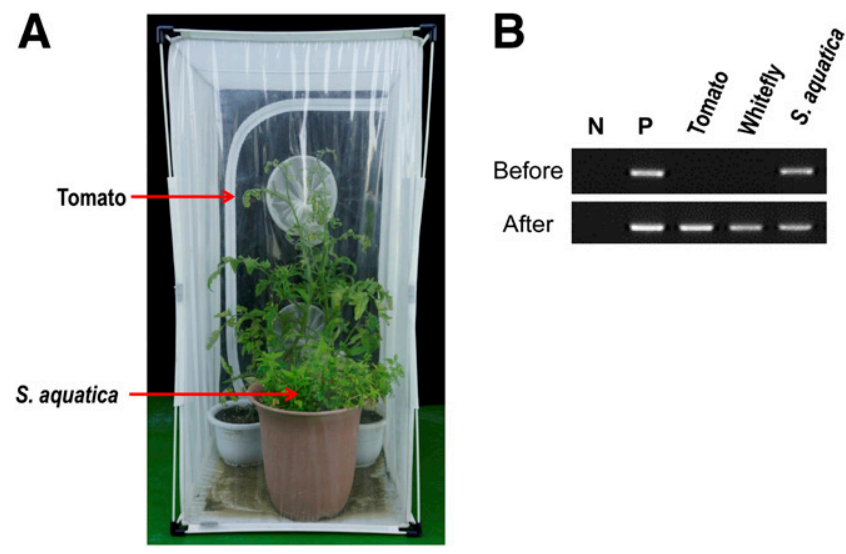

Fig. 4. Whitefly-mediated transmission of TYLCV from Stellaria aquatica to tomato plants. A, S. aquatica and tomato plants in the insect tent with whiteflies. Healthy tomato plants became TYLCV infected and showed symptoms such as leaf yellowing and curling 4 weeks later. B, Results from two polymerase chain reaction analyses conducted before and after transmission assay. Genomic DNA from tomato plants, $\mathrm{S}$. aquatica plants, and whiteflies were used as templates. Lane $\mathrm{N}=$ no template control and lane $\mathrm{P}=$ positive control with TYLCV-infected tomato genomic DNA. 
be detectable by PCR even as a vague band but it could not be enough to be detected by Southern blot hybridization without further amplification. The finding that TYLCV IR sequences from TYLCVinfected tomato plants, S. aquatica plants, and B. tabaci were identical suggests that TYLCV was transmitted among tomato and $S$. aquatica plants by B. tabaci (Fig. 2C).

To control TYLCV in fields as well as tomato greenhouses, pesticides are extensively used to control whiteflies, and TYLCV-free tomato seedlings are provided to farmers. In addition, the doors of unheated greenhouses with TYLCV infestation are opened in the winter to kill TYLCV viruliferous whiteflies. However, TYLCV reappears in greenhouses and in open fields the following spring. Thus, TYLCV-infected perennial weeds are a potential reservoir of TYLCV during winter. To investigate overwintering of TYLCV in S. aquatica, TYLCV-infected S. aquatica were left in an unheated open greenhouse from August 2012 to May 2013. The temperature inside the greenhouse dropped to as low as $-20^{\circ} \mathrm{C}$ on some days but $S$. aquatica plants remained alive. TYLCV was detected in $S$. aquatica plants during the entire winter season (Fig. 3). These results established that TYLCV can overwinter in winter-hardy S. aquatica. Whitefly-mediated transmission experiments further showed that TYLCV overwintered in S. aquatica could be transmitted to healthy tomato plants by newly introduced TYLCV-free whiteflies (Fig. 4).

This study showed a possible TYLCV transmission route from TYLCV-infected overwintering $S$. aquatica plants to new, healthy tomato plants via whiteflies. First, TYLCV-viruliferous whiteflies enter greenhouses and infect healthy tomato plants and $S$. aquatica. In summer, viruliferous whiteflies proliferate on tomato plants, and also on weeds such as $S$. aquatica. Tomato and $S$. aquatica plants infected by viruliferous whiteflies act as inoculum sources for nonviruliferous whiteflies. The transmission cycle between plants and insects repeats continually before winter onset. As the temperature gradually falls, TYLCV-infected tomato plants and viruliferous whiteflies die. However, as a winter-hardy perennial plant, S. aquatica overwinters, and TYLCV overwinters in S. aquatica. In the spring, tomato plants are replanted in these greenhouses and whiteflies enter these greenhouses (e.g., from heated greenhouses or on transplants). If these whiteflies are nonviruliferous, by feeding on TYLCV-infected $S$. aquatica and they can infect healthy tomato plants and other weeds. Thus, tomato plants in these greenhouses are eventually infected by TYLCV.

Our results suggest that TYLCV can overwinter in S. aquatica during the cold of winter and be transmitted to newly planted tomato plants by whiteflies during the next cultivation period. It means that S. aquatica can act as a "green bridge" between tomato crops in nonheated greenhouses. To prevent damage caused by TYLCV, resistant varieties of tomato or other crops have been planted in such greenhouses. However, this may not be a robust solution to control TYLCV in subsequent susceptible tomato planting if TYLCVinfected winter-hardy weeds are not completely removed inside and outside tomato greenhouses. Therefore, perennial weeds in or around tomato cultivation areas should be eliminated because they can be act as TYLCV inoculum sources.

\section{Acknowledgments}

This research was supported by a grant from the iPET (Korea Institute of Planning and Evaluation for Technology in Food, Agriculture, Forestry and Fisheries: Number 311058-05-3-HD140), Ministry for Agriculture, Food and Rural Affairs, Republic of Korea.

\section{Literature Cited}

1. Anfoka, G., Haj Ahmad, F., Abhary, M., and Hussein, A. 2009. Detection and molecular characterization of viruses associated with tomato yellow leaf curl disease in cucurbit crops in Jordan. Plant Pathol. 58:754-762.

2. Bedford, I., Kelly, A., Banks, G., Briddon, R., Cenis, J., and Markham, P. 1998. Solanum nigrum: An indigenous weed reservoir for a tomato yellow leaf curl geminivirus in southern Spain. Eur. J. Plant Pathol. 104:221-222.

3. Cohen, J., Gera, A., Ecker, R., Ben Joseph, R., Perlsman, M., Gokkes, M., Lachman, O., and Antignus, Y. 1995. Lisianthus leaf curl a new disease of lisianthus caused by tomato yellow leaf curl virus. Plant Dis. 79:416-420.

4. Corpet, F. 1988. Multiple sequence alignment with hierarchical clustering. Nucleic Acids Res. 16:10881-10890.

5. Czosnek, H., and Laterrot, H. 1997. A worldwide survey of tomato yellow leaf curl viruses. Arch. Virol. 142:1391-1406.

6. Dellaporta, S. L., Wood, J., and Hicks, J. B. 1983. A plant DNA minipreparation: Version II. Plant Mol. Biol. Rep. 1:19-21.

7. Ghanim, M., Morin, S., Zeidan, M., and Czosnek, H. 1998. Evidence for transovarial transmission of Tomato yellow leaf curl virus by its vector, the whitefly Bemisia tabaci. Virology 240:295-303.

8. Gilbertson, R. L., Rojas, M. R., Kon, T., and Jaquez, J. 2007. Introduction of Tomato yellow leaf curl virus into the Dominican Republic: The development of a successful integrated pest management strategy. Pages 279-303 in: Tomato Yellow Leaf Curl Virus Disease. Springer, The Netherlands.

9. Johnson, R. R., Black, L. L., Hobbs, H. A., Valverde, R. A., Story, R. N., and Bond, W. P. 1995. Association of Frankliniella fusca and three winter weeds with tomato spotted wilt virus in Louisiana. Plant Dis. 79:572-576.

10. Jordá, C., Font, I., Martínez, P., Juarez, M., Ortega, A., and Lacasa, A. 2001. Current status and new natural hosts of Tomato yellow leaf curl virus (TYLCV) in Spain. Plant Dis. 85:445.

11. Kashina, B. D., Mabagala, R. B., and Mpunami, A. A. 2002. Reservoir weed hosts of tomato yellow leaf curl begomovirus from Tanzania. Arch. Phytopathol. Plant Prot. 35:269-278.

12. Kil, E.-J., Park, J., Lee, H., Kim, J., Choi, H.-S., Lee, K.-y., Kim, C.-S., and Lee, S. 2014. Lamium amplexicaule (Lamiaceae): A weed reservoir for Tomato yellow leaf curl virus (TYLCV) in Korea. Arch. Virol. 159:1305-1311.

13. Lee, H., Song, W., Kwak, H.-R., Kim, J.-d., Park, J., Auh, C.-K., Kim, D.-H., Lee, K.-y., Lee, S., and Choi, H.-S. 2010. Phylogenetic analysis and inflow route of Tomato yellow leaf curl virus (TYLCV) and Bemisia tabaci in Korea. Mol. Cells 30:467-476.

14. Moriones, E., and Navas-Castillo, J. 2000. Tomato yellow leaf curl virus, an emerging virus complex causing epidemics worldwide. Virus Res. 71:123-134.

15. Navas-Castillo, J., Sánchez-Campos, S., Díaz, J. A., Sáez-Alonso, E., and Moriones, E. 1999. Tomato yellow leaf curl virus-Is causes a novel disease of common bean and severe epidemics in tomato in Spain. Plant Dis. 83:29-32.

16. Papayiannis, L., Iacovides, T., Katis, N., and Brown, J. 2010. Differentiation of Tomato yellow leaf curl virus and Tomato yellow leaf curl Sardinia virus using real-time TaqMan ${ }^{\circledR}$ PCR. J. Virol. Methods 165:238-245.

17. Papayiannis, L., Katis, N., Idris, A., and Brown, J. 2011. Identification of weed hosts of Tomato yellow leaf curl virus in Cyprus. Plant Dis. 95:120-125.

18. Park, J., Kil, E. J., Kim, J., Shin, Y. G., Heo, N. Y., and Lee, S. 2014. Rapid detection and identification of six Tomato yellow leaf curl virus isolates from different regions using polymerase chain reaction and restriction enzyme analysis. J. Phytopathol. 162:209-217.

19. Polston, J. E., Schuster, D. J., and Taylor, J. E. 2009. Identification of weed reservoirs of Tomato yellow leaf curl virus in Florida. Pages 32-33 in: 2009 Florida Tomato Institute Proceedings. Southwest Florida Research \& Education Center.

20. Reina, J., Morilla, G., Bejarano, E., Rodríguez, M., and Janssen, D. 1999. First report of Capsicum annuum plants infected by tomato yellow leaf curl virus. Plant Dis. 83:1176.

21. Rist, D., and Lorbeer, J. 1989. Occurrence and overwintering of cucumber mosaic virus and broad bean wilt virus in weeds growing near commercial lettuce fields in New York. Phytopathology 79:65-69.

22. Sánchez-Campos, S., Navas-Castillo, J., Monci, F., Diaz, J., and Moriones, E. 2000. Mercurialis ambigua and Solanum luteum: Two newly discovered natural hosts of tomato yellow leaf curl geminiviruses. Eur. J. Plant Pathol. 106:391-394.

23. Salati, R., Nahkla, M. K., Rojas, M. R., Guzman, P., Jaquez, J., Maxwell, D. P., and Gilbertson, R. L. 2002. Tomato yellow leaf curl virus in the Dominican Republic: Characterization of an infectious clone, virus monitoring in whiteflies, and identification of reservoir hosts. Phytopathology 92:487-496. 